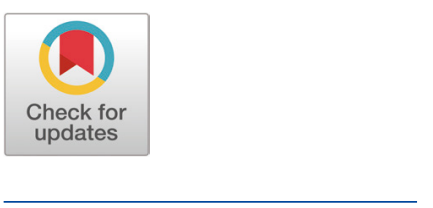

Received: Mar 19, 2020

Revised: Apr 20, 2020

Accepted: May 3, 2020

${ }^{*}$ Corresponding author

Tae-II Kim

Dairy Science Division,

National Institute of Animal Science,

Rural Development Administration,

Cheonan 31000, Korea.

Tel: +82-41-580-3388

E-mail: kimti@korea.kr

Younghoon Kim

Department of Agricultural Biotechnology and Research Institute of Agriculture and Life Science, Seoul National University,

Seoul 08826, Korea.

Tel: +82-2-880-4808

E-mail: ykeys2584@snu.ac.kr

Copyright $\odot 2020$ Korean Society of Animal Sciences and Technology.

This is an Open Access article distributed under the terms of the Creative Commons Attribution Non-Commercial License (http:// creativecommons.org/licenses/bync/4.0/) which permits unrestricted non-commercial use, distribution, and reproduction in any medium, provided the original work is properly cited.

ORCID

Dong-Hyun Lim

https://orcid.org/0000-0002-8575-0198

Vijayakumar Mayakrishnan

https://orcid.org/0000-0002-6437-1463

Hyun-Jeong Lee

https://orcid.org/0000-0002-2312-9048

Kwang-Seok Ki

https://orcid.org/0000-0003-0971-1389

Tae-ll Kim

https://orcid.org/0000-0003-0532-6010

\section{A comparative study on milk composition of Jersey and Holstein dairy cows during the early lactation}

\author{
Dong-Hyun Lim", Vijayakumar Mayakrishnan ${ }^{1}$, Hyun-Jeong Lee ${ }^{1}$, \\ Kwang-Seok Ki ${ }^{1}$, Tae-II Kim ${ }^{1 *}$ and Younghoon $\mathrm{Kim}^{2 *}$ \\ ${ }^{1}$ Dairy Science Division, National Institute of Animal Science, Rural Development Administration, \\ Cheonan 31000, Korea \\ ${ }^{2}$ Department of Agricultural Biotechnology and Research Institute of Agriculture and Life Science, Seoul \\ National University, Seoul 08826, Korea
}

\section{Abstract}

Recently, Jersey cattle was introduced and produced by embryo transfer to Korea. This study was conducted to investigate the differences of milk compositions between Jersey and Holstein cows and the relationship between days in milk (DIM) and milk compositions during early lactation. Data were collected from twelve lactating cows from Department of Animal Resources Development at National Institute of Animal Science. Cows in parity 1 were used, and calved at spring from April to March of 2017. All cows were housed in two sections within a free-stall barn, which divided into six from each breed, and received a basal total mixed ration. Milk samples of each cow were collected at 3 DIM and 30 DIM for analyzing the milk compositions, including fatty acids (FA), amino acids and minerals. Total solids, citrate, and milk urea nitrogen level were differed between the breeds $(p<0.05)$. As DIM went from 3 to 30 , milk protein, total solids, and somatic cell count decreased $(p<0.05)$, but lactose increased in all breed milk $(p<0.05)$. Citrate and free fatty acid (FFA) elevated in Jersey milk ( $p$ $<0.05)$, whereas reduced in Holstein milk $(p<0.05)$. Proportions of some individual FA varied from the breeds. Myristic (C14:0), palmitic (C16:0), and arachidonic acid (C20:4) in milk from all cows were higher at 3 DIM than at 30 DIM $(p<0.05)$. Also, stearic $(C 18: 0)$ and oleic acid $(C 18: 1)$ were lower at 3 DIM than at 30 DIM $(p<0.05)$, and the C18:1 to C18:0 ratio was significantly differed in DIM $\times$ breed interactions $(p<0.05)$. The contents of the individual amino acids did not differ from the breeds. Calcium, phosphorous, magnesium, and zinc (Zn) contents was significantly increased in Holstein milk than Jersey milk at 3 DIM. Also, $\mathrm{K}$ and $\mathrm{Zn}$ concentrations were higher in Holstein milk than in Jersey milk at 30 DIM $(p<0.05)$. It was concluded that Jersey cows would produce more effective milk in processing dairy products and more proper energy status compared with Holstein cows in early lactation under the same environmental and nutritional conditions.

Keywords: Jersey, Holstein, Milk composition, Fatty acids, Amino acids, Mineral 
Younghoon Kim

https://orcid.org/0000-0001-6769-0657

Competing interests

No potential conflict of interest relevant to

this article was reported.

Funding sources

This study was supported by the Cooperative Research Program for Agricultural Science and Technology Development (Project

Title Development of feeding management technology to increase the melatonin concentration of milk in dairy cattle; Project No: PJ01252001) of the Rural Development Administration of the Korea.

Acknowledgements

The authors are grateful to the National Institute of Animal Science's Postdoctoral Research Associate Program of the Rura Development Administration of the Korea.

Availability of data and material Upon reasonable request, the datasets of this study can be available from the corresponding author.

Authors' contributions

Conceptualization: $\mathrm{Lim} \mathrm{DH}$.

Data curation: Lim DH, Kim Y.

Methodology: Lim DH, Kim Y.

Validation: Lee HJ, Ki KS, Kim TI.

Investigation: Lim DH, MayaKrishnan V.

Writing - original draft: Lim DH.

Writing - review \& editing: MayaKrishnan V, Kim TI, Kim Y.

Ethics approval and consent to participate All dairy cows were maintained as stated in standard guidelines, and the experimental protocol involved in this research was approved by the Institutional Animal Care and Use Committee (IACUC, No. 2017252) at National Institute of Animal Science, Jeonju, Korea.

\section{INTRODUCTION}

Dairy cows experience many physiological changes at parturition, and produce the secretion in the mammary gland immediately following parturition. Their secretion is classified as colostrum, transition milk and milk in the function of time after calving. Milk and dairy products play an important role in having high nutritional value as the animal food source and positive influences on human health as well.

Milk component levels and characteristics are important factors that have a significant effect on the quality and yield of dairy products. Considerable changes in the composition of milk supplied to dairy companies can be increased processing costs by affecting the processing efficiency of dairy products and the suitability of the milk as raw materials in the food industry [1-3]. Changes in milk mineral concentrations as well as changes in milk protein and fat composition, affect suitability for processing [3].

Recently, Jersey cattle were introduced and produced by embryo transfer to Korea, which had been only Holstein cattle as lactating cow. Jersey cows are known to have low milk productivity but produce high solids in milk. The most commonly consumed milk comes from Holstein cow, but the milk of Jersey cows is recently on sale in some special regions of Korea. Currently, very small amounts of Jersey milk are produced in the country, but their dairy products are expected to be very valuable. Dairy farmers are now paid for their milk production based on fat and protein levels. Researchers and dairy farmers have more attention in raising Jersey cows because Jersey cows produce milk with high content of fat and protein, and the content of milk ingredients directly affects farmers' incomes and the processing characteristics of dairy products [4].

Bovine milk composition is influenced by many factors including breed and genotype [5-7], nutrition [8], season [9], parity [10], stage of lactation [11], as well as the physiological state of the animal [12]. Previous studies have established the potential to exploit variation of milk composition among breeds to improve milk quality $[9,13]$.

Changes in the milk composition throughout lactation have been studied extensively [14-21]; however, little is known about the composition of milk produced during the early lactation in Jersey and Holstein cows.

The aim of the present study was to compare Jersey and Holstein dairy cows in relationship with the general composition, fatty acids, amino acids and minerals content of milk at 3 days in milk (DIM) and 30 DIM under the same housing system and feeding regime.

\section{MATERIALS AND METHODS}

\section{Animals and diet}

All animal procedures were approved by the Institutional Animal Care and Use Committee (IACUC, No. 2017-252) at the National Institutional of Animal Science (NIAS, Jeonju, Korea).

A total of 6 Jersey and 6 Holstein cows were in the first lactation, and calved at spring of 2017, so that mean calving date was April $27 \pm 14.85 \mathrm{~d}$ for Jersey and April $29 \pm 13.55 \mathrm{~d}$ for Holstein cows. All cows housed in two sections within a free-stall barn, which divided into six from each breed at the experimental dairy farm, Department of Animal Resources Development, NIAS, Cheonan, Korea.

All cows had free access to water and offered a basal total mixed ration (TMR) diet ad libitum. The TMR was mixed once daily and fed at $0900 \mathrm{~h}$. The TMR contained $25.02 \%$ corn silage, $5.65 \%$ alfalfa hay, $16.51 \%$ mixed haylage, $3.77 \%$ tall fescue hay, $3.72 \%$ beet pulp, $3.73 \%$ cottonseed, $1.88 \%$ soybean meal, $38.87 \%$ the concentrate, and $0.84 \%$ other additives including mineral, sodium bicar- 
bonate and bypass fat based on dry matter. Net energy for lactation $\left(\mathrm{NE}_{\mathrm{L}}\right)$ of the TMR was calculated $1.7 \mathrm{Mcal} / \mathrm{kg}$ based on national research council (NRC) [22] requirements.

\section{Sampling, measurements and analyses}

Milk was collected on 3 DIM and 30 DIM, which was sampled on a one day consecutive morning-evening milking from each cow. Cows were milked in a herringbone milking parlour twice a day (0600 and 1700 h). Milk samples were divided into 2 subsamples; First subsample of each cow immediately determined using milk composition analyzer (LactoScop MK2, Delta Instruments, the Netherlands) for milk component including milk fat, protein, lactose, total solids (TS), citrate, milk urea nitrogen (MUN), free fatty acid (FFA), and somatic cell count (SCC). Second subsample was stored at $-80^{\circ} \mathrm{C}$ until analyzed, and used for the analysis of fatty acids (FA), amino acids (AA), and mineral contents in each cow's milk. Fat was isolated from the milk samples to determine the FA composition by centrifuging thawed milk at $21,000 \times \mathrm{g}$ for $30 \mathrm{~min}$ at $4^{\circ} \mathrm{C}$. The amount of fat, protein, lactose and TS percentage can be calculated using the following formula.

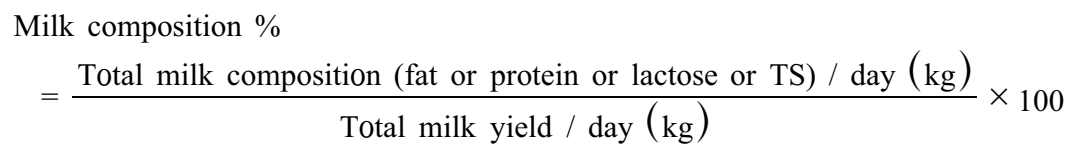

FA in milk fat was converted to fatty acid methyl esters (FAMEs) using a modified version of Bannon et al. [23]. Separation and identification of FAMEs were performed using gas chromatography (Agilent 6890, Agilent Technologies, CA, USA) equipped with a flame ionization detector (FID) and a fused silica capillary column (30 m $\times 0.32 \mathrm{~mm} \times 0.25 \mu \mathrm{m}$, OmegawaxTM 320, Supelco, Bellefonte, PA, USA). Separated FAMEs were identified by retention time comparison and results were calculated using response factors derived from quantitative chromatographic standards of known composition ( $\mathrm{Nu}$ Chek Prep). The injector, detector, and oven temperatures were set at $250^{\circ} \mathrm{C}, 260^{\circ} \mathrm{C}$, and $200^{\circ} \mathrm{C}$, respectively. All analytical results were expressed in wt $\%$ (g FA / $100 \mathrm{~g}$ of FAs).

AA composition was determined using ion-exchange chromatography with an AA analyzer (Type Model 835-50, Hitachi, Japan) with a C18 column $(4.6 \times 250 \mathrm{~mm}, 5 \mu \mathrm{m}$, Waters, Milford, MA, USA). The resulting sample was determined at $38^{\circ} \mathrm{C}$ and detected a flow rate of $1.0 \mathrm{~mL} / \mathrm{min}$ at $254 \mathrm{~nm}$.

Mineral contents were determined using an inductively coupled plasma-automic emission spectrometer (ICPS 7510, Shimadzu, Kyoto, Japan) after digestion with $\mathrm{HNO}_{3}$ using a microwave digestion system (Ethos 1, Milestone, Sorisole, Italy).

\section{Statistical analysis}

The date, fat, protein, lactose, TS, citrate, MUN, FFA, SCC, FA, AA and minerals in milk were recorded. All the raw data were prepared on Microsoft Excel (Microsoft, Redmond, WA, USA) and then analyzed with the statistical package SAS Enterprise Guide 7.1 (SAS Institute, Cary, NC, USA).

The effects of breed and DIM on the composition of colostrum and milk were analyzed with multiple analysis of variance (GLM procedure). The null hypothesis was rejected if $p<0.05$. In the case of the rejection of the null hypothesis Duncan's multiple range test was applied for the comparison of means. In order to analyze the differences between breeds within the same analytical parameters, one-way analysis of variance (ANOVA procedure) was applied for all compositions of 3 DIM and 30 DIM. 


\section{RESULTS}

The milk compositions of primiparous Jersey and Holstein cows at 3 DIM and 30 DIM were presented in Table 1 and Fig. 1. In this study, the sampling of different breeds should be accomplished at the same time after parturition since the milk compositions are rapidly changing in the first few days after calving.

The fat, protein, lactose, and TS concentrations in Jersey milk were 4.82\%, $6.43 \%, 3.85 \%$, and $15.7 \%$ at 3 DIM, and were $4.99 \%, 3.26 \%, 4.72 \%$, and $13.66 \%$ at 30 DIM, respectively. For Holstein, the fat, protein, lactose, and TS concentrations were $4.67 \%, 7.4 \%, 4.24 \%, 19.92 \%$ at 3 DIM, and were $4.12 \%, 2.82 \%, 4.89 \%, 12.55 \%$ at 30 DIM, respectively. As the DIM advanced, the milk protein contents in both breeds decreased $(p<0.05)$, while lactose increased significantly $(p<0.05)$. The milk compositions such as fat, protein, and lactose contents at 3 DIM were not significantly changed between breeds. However, fat, protein, and TS content were significantly increased in Jersey milk than that of Holstein milk at 30 DIM. SCC in Jersey milk was significantly lowers (1,390 $\left.\times 10^{3} / \mathrm{mL}\right)$ than in Holstein cow milk $\left(2,034 \times 10^{3} / \mathrm{mL}\right)$ at 3 DIM. However, SCC in Jersey milk was significantly higher $\left(131.6 \times 10^{3} / \mathrm{mL}\right)$ than in Holstein milk $\left(55.67 \times 10^{3} / \mathrm{mL}\right)$ at $30 \mathrm{DIM}(p<$ $0.05)$. Citrate in Jersey milk was significantly less at $3 \mathrm{DIM}(2.84 \mathrm{mmol} / \mathrm{L})$ than at $30 \mathrm{DIM}(3.17$ $\mathrm{mmol} / \mathrm{L})(p<0.05)$, but in Holstein milk was significantly more at $3 \mathrm{DIM}(6.08 \mathrm{mmol} / \mathrm{L})$ than at $30 \mathrm{DIM}(2.79 \mathrm{mmol} / \mathrm{L})(p<0.05)$.

The entire FA profile of milk produced by Holstein and Jersey cows was presented in Table 2. The proportion of long chain FA as stearic acid (C18:0) and oleic acid (C18:1 n-9) was low at 3 $\mathrm{DIM}$, and thereafter increased at $30 \mathrm{DIM}$. However, the proportion of myristic (C14:0), palmitic (C16:0), and arachidonic acid (C16:1) were higher in milk fat at $3 \mathrm{DIM}(10.15 \%, 36.15 \%$, and $0.52 \%$ in Jersey milk; $12.13 \%, 40.82 \%$, and $0.46 \%$ in Holstein milk, respectively) than that at 30 DIM $(8.81 \%, 32.02 \%$, and $0.23 \%$ in Jersey milk; $8.53 \%, 31.25 \%$, and $0.33 \%$ in Holstein milk, respectively) of all breed cows $(p<0.05)$. Stearic (C18:0) and oleic acid (C18:1 n-9) were lower in milk fat at 3 DIM (13.53\% and 32.73\% in Jersey milk; $10.76 \%$ and $29.42 \%$ in Holstein milk, respectively) than that at 30 DIM (17.88\% and 35.16\% in Jersey milk; $16.67 \%$ and $37.33 \%$ in Holstein milk, respectively) of all breed cows $(p<0.05)$. The level of saturated fatty acids (SFA), mono- (MUFA), poly- unsaturated fatty acids (PUFA) and C18:1 to C18:0 ratio were significantly changed at 3 DIM to 30 DIM in both breed $(p<0.05)$. From our study results, Jersey milk had a higher level of C18:0 (2.77\%), C18:1 (3.31\%), C20:4 (0.06\%), MUFA (3.11\%), and PUFA (0.76\%), and lower

Table 1. Milk compositions of Jersey and Holstein cows at 3 DIM and 30 DIM

\begin{tabular}{|c|c|c|c|c|c|c|c|c|}
\hline \multirow{2}{*}{ Item } & \multicolumn{2}{|c|}{ Jersey } & \multicolumn{2}{|c|}{ Holstein } & \multirow{2}{*}{ SEM } & \multicolumn{3}{|c|}{$p$-value } \\
\hline & 3 DIM & 30 DIM & 3 DIM & 30 DIM & & DIM & Breed & DIM $\times$ Breed \\
\hline Fat (\%) & $4.82 \pm 0.37$ & $4.99 \pm 0.25$ & $4.67 \pm 0.50$ & $4.12 \pm 0.22$ & 0.23 & 0.625 & 0.465 & 0.506 \\
\hline Protein (\%) & $6.43 \pm 0.48^{x}$ & $3.26 \pm 0.03^{y}$ & $7.47 \pm 0.89^{x}$ & $2.82 \pm 0.08^{y}$ & 0.36 & $<0.001$ & 0.381 & 0.330 \\
\hline Lactose $(\%)$ & $3.85 \pm 0.11^{y}$ & $4.72 \pm 0.19^{x}$ & $4.24 \pm 0.12^{y}$ & $4.89 \pm 0.04^{x}$ & 0.08 & $<0.001$ & 0.823 & 0.537 \\
\hline Total solids (\%) & $15.73 \pm 0.55$ & $13.66 \pm 0.37$ & $19.92 \pm 1.30^{x}$ & $12.55 \pm 0.27^{y}$ & 0.34 & $<0.001$ & 0.004 & 0.007 \\
\hline $\operatorname{SCC}\left(\times 10^{3} / \mathrm{mL}\right)$ & $1,390 \pm 210.6^{x}$ & $131.6 \pm 63.8^{y}$ & $2,034 \pm 502.2^{x}$ & $55.67 \pm 14.18^{y}$ & 169.19 & $<0.001$ & 0.201 & 0.331 \\
\hline Citrate $(\mathrm{mmol} / \mathrm{L})$ & $2.84 \pm 0.07^{y}$ & $3.17 \pm 0.12^{x}$ & $6.08 \pm 1.18^{x}$ & $2.79 \pm 0.06^{y}$ & 0.47 & 0.017 & $<0.001$ & $<0.001$ \\
\hline MUN (mg/dL) & $5.61 \pm 0.53$ & $7.60 \pm 0.21$ & $22.31 \pm 3.29^{x}$ & $7.77 \pm 0.30^{y}$ & 1.01 & 0.125 & $<0.001$ & $<0.001$ \\
\hline $\mathrm{FFA}(\mathrm{mmol} / 100 \mathrm{~g})$ & $1.04 \pm 0.21^{y}$ & $8.97 \pm 1.02^{x}$ & $5.01 \pm 0.93^{x}$ & $1.11 \pm 0.13^{y}$ & 0.38 & $<0.001$ & 0.380 & $<0.001$ \\
\hline
\end{tabular}

Values are expressed as mean \pm SEM of 6 dairy cows in each group.

${ }^{x, y}$ Denote comparisons made between 3 DIM and 30 DIM in each breed group $(p<0.05)$.

DIM, days in milk; SEM, standard error of means; SCC, somatic cell count; MUN, milk urea nitrogen; FFA, free fatty acid. 

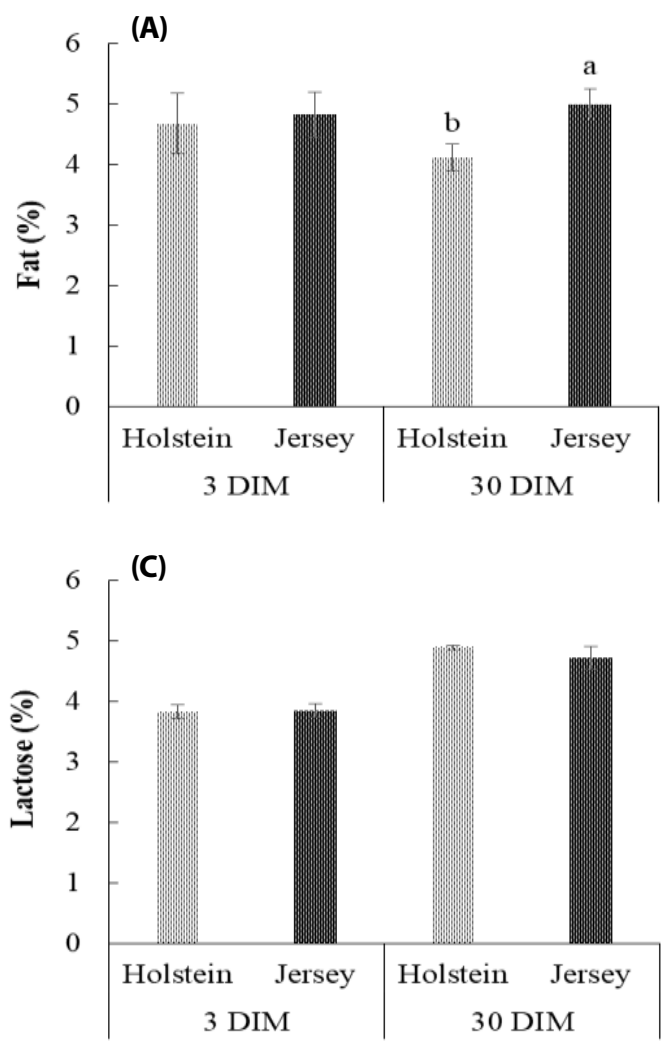

(E)
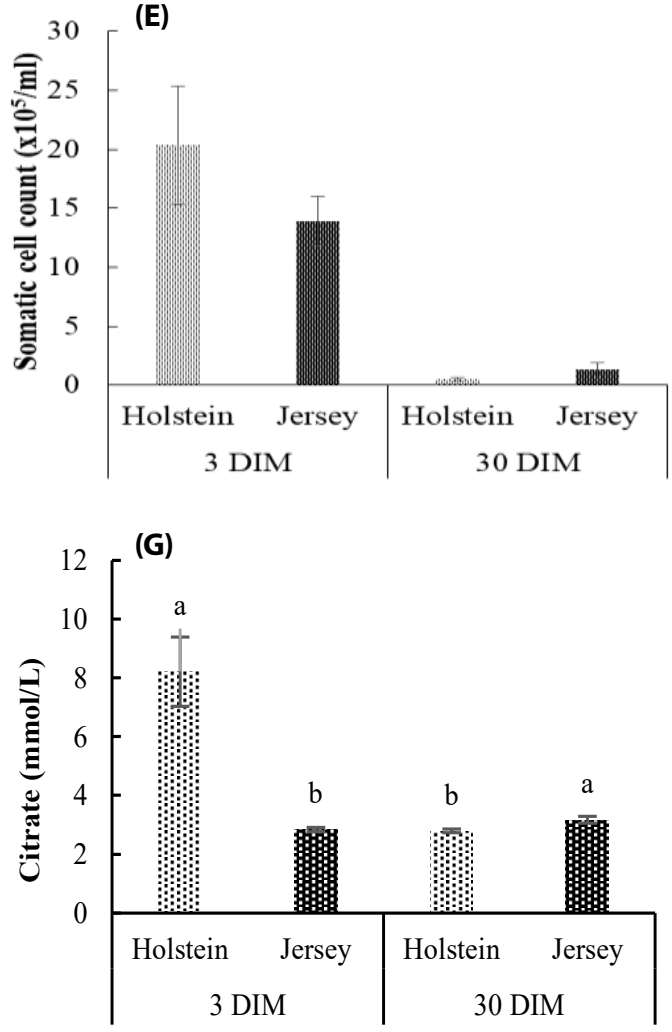

(B)

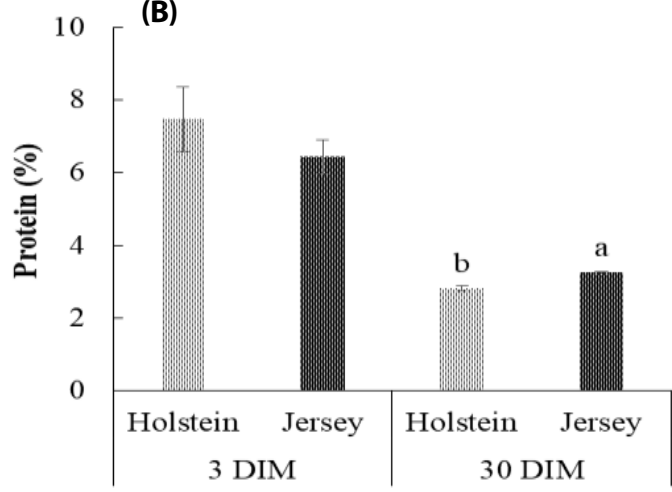

(D)

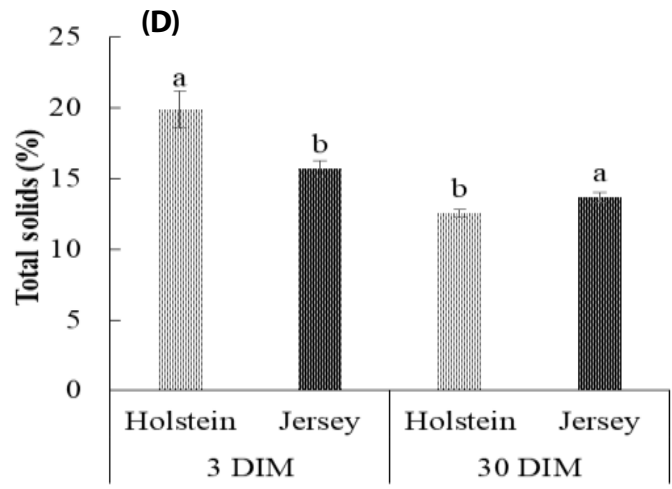

(F)

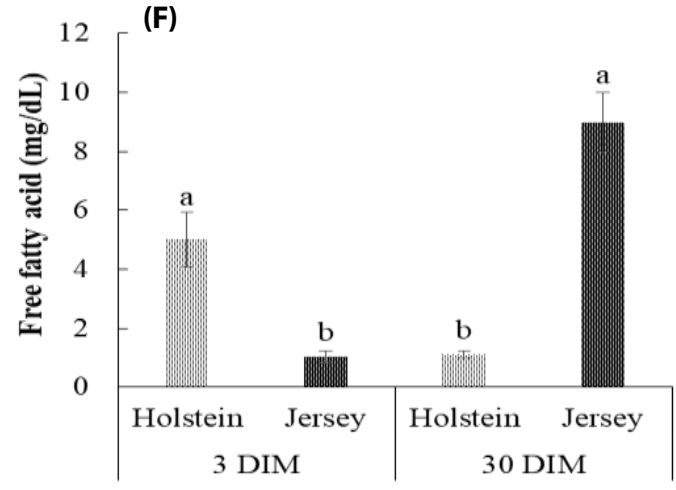

(H)

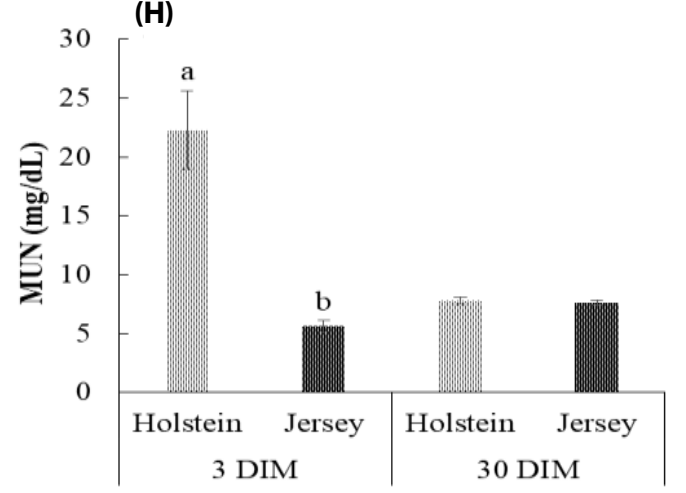

Fig. 1. The chemical composition of colostrum and normal milk obtained from primiparous Jersey and Holstein cows (A, fat; B, protein; C, lactose; D, total solids; E, somatic cell count; F, free fatty acid; G, citrate; H, milk urea nitrogen (MUN); ${ }^{a, b}$ Denote comparisons made between Jersey and Holstein milk in 3 DIM or 30 DIM, $p<0.05$ ). DIM, days in milk. 
Table 2. Fatty acid compositions (\%) in the milk of Jersey and Holstein cows at 3 DIM and 30 DIM

\begin{tabular}{|c|c|c|c|c|c|c|c|c|}
\hline \multirow{2}{*}{ Fatty acid } & \multicolumn{2}{|c|}{ Jersey } & \multicolumn{2}{|c|}{ Holstein } & \multirow{2}{*}{ SEM } & \multicolumn{3}{|c|}{$p$-value } \\
\hline & 3 DIM & 30 DIM & 3 DIM & 30 DIM & & DIM & Breed & DIM $\times$ Breed \\
\hline \multicolumn{9}{|l|}{$\%$ of total fatty acid } \\
\hline C14:0 (Myristic acid) & $10.15 \pm 0.45^{x}$ & $8.81 \pm 0.36^{y}$ & $12.13 \pm 1.40^{x}$ & $8.53 \pm 0.60^{y}$ & 0.30 & 0.005 & 0.347 & 0.151 \\
\hline C16:0 (Palmitic acid) & $36.15 \pm 0.79^{x}$ & $32.02 \pm 0.84^{y}$ & $40.82 \pm 4.05^{x}$ & $31.25 \pm 0.96^{y}$ & 0.67 & $<0.001$ & 0.286 & 0.087 \\
\hline C16:I n-7 (Palmitoleic acid) & $2.71 \pm 0.08$ & $2.47 \pm 0.11$ & $3.04 \pm 0.03$ & $2.77 \pm 0.10$ & 0.06 & 0.059 & 0.060 & 0.940 \\
\hline C18:0 (Stearic acid) & $13.53 \pm 0.50^{y}$ & $17.88 \pm 0.84^{x}$ & $10.76 \pm 1.49^{y}$ & $16.67 \pm 1.44^{x}$ & 0.54 & $<0.001$ & 0.116 & 0.515 \\
\hline C18:I n-9 (Oleic acid) & $32.73 \pm 0.85^{y}$ & $35.16 \pm 0.85^{x}$ & $29.42 \pm 4.00^{y}$ & $37.33 \pm 0.55^{x}$ & 0.62 & 0.007 & 0.855 & 0.096 \\
\hline C18:2 n-6 (Linoleic acid) & $3.20 \pm 0.35$ & $2.56 \pm 0.08$ & $2.64 \pm 0.12$ & $2.33 \pm 0.08$ & 0.18 & 0.087 & 0.446 & 0.738 \\
\hline C18:3 n-6 ( $($-Linoleic acid) & $0.13 \pm 0.01$ & $0.12 \pm 0.01$ & $0.12 \pm 0.01$ & $0.13 \pm 0.00$ & 0.01 & 0.761 & 0.973 & 0.515 \\
\hline C18:3 n-3 (Linolenic acid) & $0.43 \pm 0.05$ & $0.33 \pm 0.02$ & $0.29 \pm 0.03$ & $0.29 \pm 0.04$ & 0.03 & 0.200 & 0.121 & 0.497 \\
\hline C20:I n-9 (Eicosenoic acid) & $0.46 \pm 0.04$ & $0.42 \pm 0.01$ & $0.34 \pm 0.03$ & $0.37 \pm 0.01$ & 0.02 & 0.463 & 0.180 & 0.561 \\
\hline C20:4 n-6 (Arachidonic acid) & $0.52 \pm 0.05^{\mathrm{x}}$ & $0.23 \pm 0.04^{y}$ & $0.46 \pm 0.04^{x}$ & $0.33 \pm 0.09^{y}$ & 0.03 & $<0.001$ & 0.710 & 0.337 \\
\hline Saturated fatty acids & $59.83 \pm 0.95^{x}$ & $58.71 \pm 0.96^{y}$ & $63.70 \pm 3.96^{x}$ & $56.45 \pm 0.49^{y}$ & 0.65 & 0.023 & 0.651 & 0.090 \\
\hline Monounsaturated fatty acids & $35.90 \pm 0.90^{y}$ & $38.05 \pm 0.93^{x}$ & $32.79 \pm 4.00^{y}$ & $40.47 \pm 0.56^{x}$ & 0.64 & 0.019 & 0.970 & 0.113 \\
\hline Polyunsaturated fatty acids & $4.27 \pm 0.41^{x}$ & $3.24 \pm 0.13^{y}$ & $3.51 \pm 0.05^{\mathrm{x}}$ & $3.08 \pm 0.19^{y}$ & 0.21 & 0.026 & 0.839 & 0.600 \\
\hline C18:0: C18:I & $2.47 \pm 0.09^{x}$ & $2.06 \pm 0.14^{y}$ & $2.74 \pm 0.01^{x}$ & $2.29 \pm 0.16^{y}$ & 0.07 & 0.007 & 0.372 & 0.049 \\
\hline
\end{tabular}

Values are expressed as mean \pm SEM of 6 dairy cows in each group.

${ }^{x, y}$ Denote comparisons made between 3 DIM and 30 DIM in each breed group $(p<0.05)$.

DIM, days in milk; SEM, standard error of means.

level of C14:0 (1.98\%), C16:0 (4.67\%) and SFA (3.87\%) in Holstein milk at 3 DIM. Also, Jersey milk had an increased level of C14:0 (0.28\%), C16:0 (0.7\%), C18:0 (1.21\%), SFA (2.26\%), and PUFA (0.16\%), and decreased level of C18:1 (2.17\%), C20:4 (0.1\%), and MUFA (2.42\%) than that of Holstein milk at 30 DIM (Fig. 2).

The amino acid (AA) content of milk did not differ between Jersey and Holstein cows (Table 3). The essential AAs were higher in milk of Holstein cows than that of Jersey cows at 3 DIM, while were lower in milk of Holstein cows than that of Jersey cows at 30 DIM, numerically. As the milk protein content decreased over time, the AA profiles were observed the same tendency from 3 DIM to $30 \mathrm{DIM}(p<0.05)$.

The changes in mineral elements concentration in Jersey and Holstein milk at 3 DIM and 30 DIM were presented in Table 4. Holstein milk had higher content of calcium (Ca; $1,946.67 \mathrm{mg} /$ $\mathrm{kg}$ ), phosphorous (P; 1,864.25 mg/kg), potassium (K; 1,440.28 mg/kg), magnesium (Mg; 289.98 $\mathrm{mg} / \mathrm{kg})$, ferrous $(\mathrm{Fe} ; 2.63 \mathrm{mg} / \mathrm{kg})$ and zinc $(\mathrm{Zn} ; 21.95 \mathrm{mg} / \mathrm{kg})$ than that of Jersey milk $(1,611.82$ $\mathrm{mg} / \mathrm{kg} ; 1,449.82 \mathrm{mg} / \mathrm{kg} ; 1,012.84 \mathrm{mg} / \mathrm{kg} ; 184.00 \mathrm{mg} / \mathrm{kg} ; 2.01 \mathrm{mg} / \mathrm{kg}$ and $8.59 \mathrm{mg} / \mathrm{kg}$ respectively) at 3 DIM. However, Jersey milk had higher content of Ca, P, Mg, and Zn $(1,168.89 \mathrm{mg} / \mathrm{kg}, 1,023.08$ $\mathrm{mg} / \mathrm{kg}, 115.40 \mathrm{mg} / \mathrm{kg}$, and $3.73 \mathrm{mg} / \mathrm{kg}$, respectively); and lower content of $\mathrm{K}(1,002.56 \mathrm{mg} / \mathrm{kg})$ and $\mathrm{Fe}(1.83 \mathrm{mg} / \mathrm{kg})$ than that of Holstein milk $(857.68 \mathrm{mg} / \mathrm{kg}, 922.60 \mathrm{mg} / \mathrm{kg}, 92.23 \mathrm{mg} / \mathrm{kg}$, and 2.92 $\mathrm{mg} / \mathrm{kg}$, respectively) at $30 \mathrm{DIM}(p<0.05)$.

\section{DISCUSSION}

The main objective of this study was to compare Jersey and Holstein dairy cows in relationship with the milk composition, fatty acids, amino acids, and minerals of milk at 3 DIM and 30 DIM under the same TMR diet across the early lactation.

In the current study, the primiparous of two breed cows were used since suggested by Bainbridge 

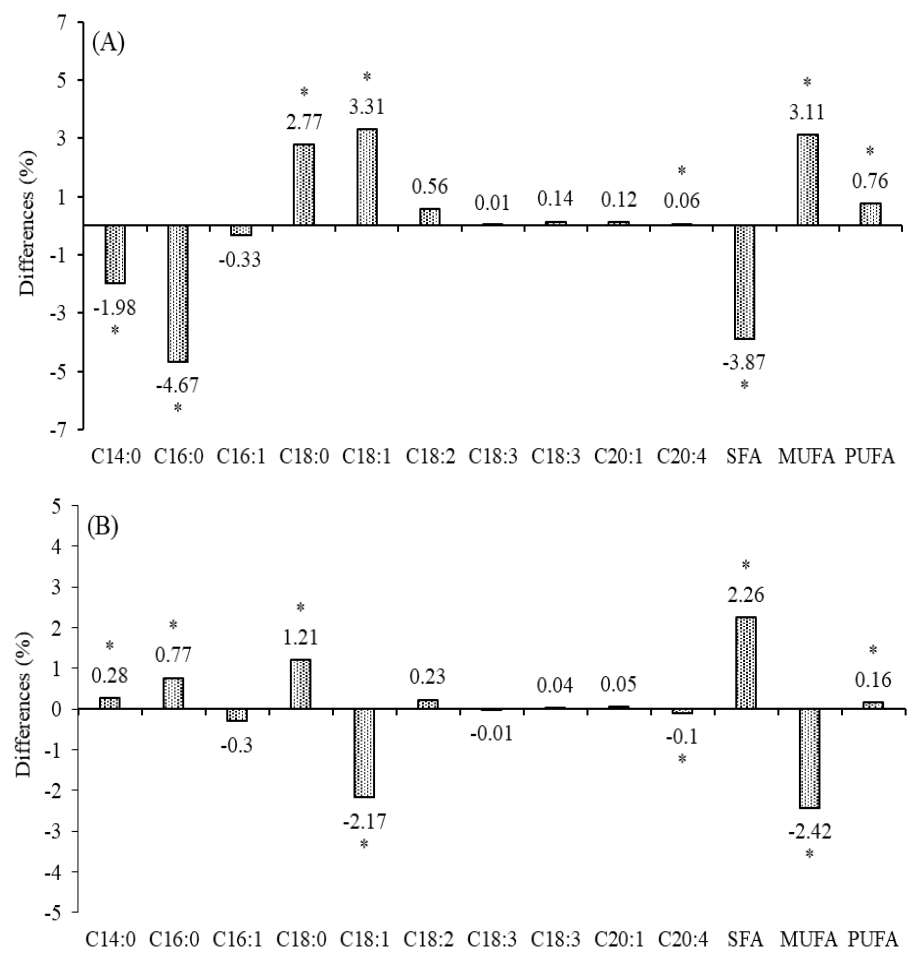

Fig. 2. Differences (\%) for the fatty acid profile at 3 DIM (A) and 30 DIM (B) of Jersey milk compared with Holstein milk ( ${ }^{*} \boldsymbol{p}<\mathbf{0 . 0 5}$ ). C14:0, myristic acid; C16:0, palmitic acid; C16:I n-7, palmitoleic acid; C18:0, stearic acid; C18:I n-9, oleic acid; C18:2 n-6, linoleic acid; C18:3 n-6, y-linoleic acid; C18:3 n-3, linolenic acid; C20:I $\mathrm{n}-9$, eicosenoic acid; C20:4 n-6, arachidonic acid; SFA, saturated fatty acid; MUFA, monounsaturated fatty acid; PUFA, polyunsaturated fatty acid.

Table 3. Amino acid compositions (\%) in the milk of Jersey and Holstein cows at 3 DIM and 30 DIM

\begin{tabular}{|c|c|c|c|c|c|c|c|c|}
\hline \multirow{2}{*}{ Item } & \multicolumn{2}{|c|}{ Jersey } & \multicolumn{2}{|c|}{ Holstein } & \multirow{2}{*}{ SEM } & \multicolumn{3}{|c|}{$p$-value } \\
\hline & 3 DIM & 30 DIM & 3 DIM & 30 DIM & & DIM & Breed & DIM $\times$ Breed \\
\hline \multicolumn{9}{|l|}{$\%$ of the milk sample } \\
\hline Cysteine & 0.097 & 0.045 & 0.153 & 0.043 & 0.008 & $<0.001$ & 0.186 & 0.167 \\
\hline Methionine & 0.137 & 0.081 & 0.142 & 0.071 & 0.009 & 0.001 & 0.933 & 0.743 \\
\hline Asparagine & 0.578 & 0.291 & 0.766 & 0.277 & 0.040 & $<0.001$ & 0.391 & 0.322 \\
\hline Threonine & 0.401 & 0.185 & 0.578 & 0.180 & 0.031 & $<0.001$ & 0.234 & 0.241 \\
\hline Serine & 0.514 & 0.237 & 0.693 & 0.227 & 0.038 & $<0.001$ & 0.386 & 0.334 \\
\hline Glutamine & 1.326 & 0.738 & 1.584 & 0.692 & 0.081 & $<0.001$ & 0.609 & 0.467 \\
\hline Glycine & 0.190 & 0.081 & 0.259 & 0.078 & 0.015 & $<0.001$ & 0.404 & 0.365 \\
\hline Alanine & 0.273 & 0.134 & 0.359 & 0.122 & 0.020 & $<0.001$ & 0.459 & 0.338 \\
\hline Valine & 0.433 & 0.215 & 0.557 & 0.193 & 0.031 & $<0.001$ & 0.523 & 0.370 \\
\hline Isoleucine & 0.304 & 0.162 & 0.348 & 0.144 & 0.019 & $<0.001$ & 0.790 & 0.523 \\
\hline Leucine & 0.716 & 0.373 & 0.892 & 0.344 & 0.047 & $<0.001$ & 0.537 & 0.395 \\
\hline Tyrosine & 0.370 & 0.157 & 0.463 & 0.147 & 0.028 & $<0.001$ & 0.543 & 0.460 \\
\hline Phenylalanine & 0.348 & 0.187 & 0.417 & 0.175 & 0.022 & $<0.001$ & 0.605 & 0.464 \\
\hline Lysine & 0.562 & 0.295 & 0.718 & 0.276 & 0.037 & $<0.001$ & 0.476 & 0.363 \\
\hline Histidine & 0.178 & 0.093 & 0.231 & 0.090 & 0.012 & $<0.001$ & 0.426 & 0.379 \\
\hline Arginine & 0.274 & 0.123 & 0.379 & 0.123 & 0.022 & $<0.001$ & 0.367 & 0.333 \\
\hline Proline & 0.660 & 0.370 & 0.865 & 0.370 & 0.045 & 0.001 & 0.443 & 0.335 \\
\hline
\end{tabular}

DIM, days in milk; SEM, standard error of means. 
Table 4. Mineral compositions in the milk of Jersey and Holstein cows at 3 DIM and 30 DIM

\begin{tabular}{|c|c|c|c|c|c|c|c|c|}
\hline \multirow{2}{*}{ Item } & \multicolumn{2}{|c|}{ Jersey } & \multicolumn{2}{|c|}{ Holstein } & \multirow{2}{*}{ SEM } & \multicolumn{3}{|c|}{$p$-value } \\
\hline & 3 DIM & $30 \mathrm{DIM}$ & 3 DIM & 30 DIM & & DIM & Breed & DIM $\times$ Breed \\
\hline \multicolumn{9}{|c|}{ Mineral compositions $(\mathrm{mg} / \mathrm{kg})$} \\
\hline $\mathrm{Ca}$ & $1,611.82$ & $1,168.89$ & $1,946.67$ & 857.68 & 72.92 & 0.001 & 0.942 & 0.093 \\
\hline$P$ & $1,449.82$ & $1,023.08$ & $1,864.25$ & 922.60 & 60.65 & $<0.001$ & 0.285 & 0.086 \\
\hline $\mathrm{K}$ & $1,012.84^{y}$ & 946.80 & $1,440.28^{x}$ & $1,002.56$ & 38.67 & 0.134 & 0.031 & 0.095 \\
\hline $\mathrm{Mg}$ & $184.00^{y}$ & 115.40 & $289.98^{x}$ & 92.23 & 11.40 & $<0.001$ & 0.138 & 0.024 \\
\hline $\mathrm{Fe}$ & 2.01 & 1.45 & 2.63 & 1.83 & 0.16 & 0.072 & 0.298 & 0.790 \\
\hline $\mathrm{Zn}$ & $8.59^{y}$ & 3.73 & $21.95^{x}$ & 2.92 & 1.08 & 0.001 & 0.023 & 0.011 \\
\hline
\end{tabular}

${ }^{x, y}$ Denote comparisons made between 3 DIM and 30 DIM in each breed group $(p<0.05)$.

DIM, days in milk; SEM, standard error of means.

et al. [24], which reported that the parity influences on the component of milk. The milk fat and protein percentage in Jersey cows was higher than those of Holstein cows at 30 DIM. These results were consistent with previous research between Holstein and Jersey [24-26]. Bainbridge et al. [24] reported that the fat and protein percentage of Holstein milk decreased from 5 DIM to 95 DIM, while in Jersey milk, the protein percentage decreased, and the fat percentage increased from 5 DIM to 95 DIM. This study observed that the milk protein decreased, and lactose increased in both breeds as DIM increased. Our study results are agreed with Tsioulpas et al. (2007) who reported that the lactose content was low on the first day after calving and then increased gradually thereafter up to 60 days.

Citrate plays a role in milk-processing by interacting with other milk constituents to influence the coagulation of milk protein and produces the distinct aromatic flavor of fermented milk product [27]. Citrate content in this study was higher in Jersey milk than in Holstein milk at 30 DIM. These results suggest that Jersey milk can be more effective in the processing such as a fermented cheese making compared with Holstein milk.

MUN is a final product of protein metabolism and is negatively related to energy level of diet [28]. This study showed that MUN levels of all cows at 30 DIM was lower than the normal value $(10-14 \mathrm{mg} / \mathrm{dL})$ that reported by Taytak and Bayram [29], which is optimum MUN levels for medium and low-yield dairy cattle. It is understandable that low MUN level of all breed milk at 30 DIM arose from lower milk production of cows in first lactation compared with multiparous cows.

The amount of lactose present in the milk can itself act as an indicator of mammary gland health, being more sensitive to detect an SCC increase than other components [30]. In the present study, DIM influenced the percentage of lactose in the milk. The two breed cows had higher lactose percentage in the 30 DIM. An earlier study demonstrated that the higher level of SCC milk had low level of lactose content [30]; it may be due to the leakage in the blood-milk barrier, in addition to the reduced biosynthetic potential of secretory cells [31].

In this study TS content of Jersey and Holstein cow milk meet the milk composition standard requirement for cows of 12.8\%-14.5\% [32]. Our study results are agreed by Nevens [33] who reported earlier that the higher TS percentage was higher (12.27\% to 14.54\%) in Ayrshire, Brown Swiss, Guersey, Holstein and Jersey. Also, our result supported with one more study who reported earlier that the Indian dairy cattle showed the milk TS percent ranged from $12.20 \%$ to $15.0 \%$ [34].

SCC is one of the predictor which mostly used for sub-clinical mastitis in dairy cows [35], and this SCC was highest shortly after calving, declined rapidly to a nadir between days 25 and 45 and then rose slowly throughout the rest of lactation cycle [36]. Breed and DIM had significant effects on SCC in the milk. Interaction effect was detected between DIM and breed. The high-producing 
cattle breed such as Holstein cows had a higher value in SCC when at 3 DIM case was present in comparison with Jersey cows. Similar findings was reported by Banga et al. [37] which reported that SCC value was higher in Holstein milk than in than Jersey cow milk. There seems to be breed differences between Holstein and Jersey cows in the innate immune responses to Staphylococcus aureus intramammary infection as observed in other studies [38].

An FFA content increase implies either to the deteriorated health state of dairy cow or to fat decomposition as a consequence of milk microbial contamination which is usually caused by undesirable psychrotrophic or thermo-resistant microflora [39]. The negative energy balance of cows occurred by increasing milk yield in early lactation, and can lead to mobilize the body fat for energy acquirement [40]. Thus at first the FFA content are high in milk. This study appeared that the FFA of Holstein cows decreased, while the FFA of Jersey cows increased as DIM progressed from $3 \mathrm{~d}$ to $30 \mathrm{~d}$. The increased FFA content of Jersey milk in this study can be predicted, as Jersey cows experience the negative energy balance, which produced more milk fat and protein, compared to Holstein cows. Also, it appeared to relate with higher SCC in Jersey milk than that of Holstein milk. An increased FFA causes a slightly bitter smack in the dairy product [40], and impairs the milk fermentation progress [41].

SFA, MUFA and PUFA in this study changed significantly as DIM increased from $3 \mathrm{~d}$ to 30 d. However, there were no significant differences between Holstein and Jersey milk. These results are different from Soyeurt et al. [42], which reported that the FA of milk were influenced by dairy breed. It can be attributable that two breed cows fed the same TMR diet to remove the effect of the diet as a major factor affecting the FA profile of milk fat [43]. Oleic acid (C18:1 n-9) in milk fat is a biomarker for negative energy balance during the early lactation or in ketosis-arousing period [44]. On these differences, Medrano et al. [45] proposed that this reason is due to differences between breeds in the activity of stearoyl coenzyme A desaturase (SCD; also known as $\triangle 9$-desaturase), which secreted in the mammary. SCD oxidizes stearic acids (C18:0) to oleic acids (C18:1) and is involved in conjugated linoleic acid (CLA) production, which has positive health benefit to inhibit cancer and carcinogen [45-47]. Some FA composition of milk fat in this study showed significantly difference between 3 DIM and 30 DIM. These changes were caused by continually decreasing amounts of FA, which obtained from mobilized adipose tissue as cows experienced an energy imbalance by supplied the diet with insufficient energy level related to MUN in the early lactation [48]. Another important reason for the difference in MUN values between Holstein and Jersey milk at 3 and $30 \mathrm{DIM}$ is a difference in MUN efficiency of $\mathrm{N}$ digestion in early lactation [49].

All AAs in this study showed a significant decrease from 3 DIM to 30 DIM. Essential AAs such as methionine, threonine, valine, isoleucine, leucine, phenylalanine, lysine, and histidine were numerically included more in Jersey milk than in Holstein milk at 30 DIM. The protein contents of milk depend mostly on breed, lactation status, and age. The amount of the essential AAs in milk between breeds is proportional to the protein contents [50]. Csapo et al. [50] found that the higher protein content in the case of Jersey was accompanied with higher essential AA concentrations in Jersey milk than in Holstein milk, but the AA profile of milk protein did not differ notably by breeds.

The concentrations of $\mathrm{Ca}, \mathrm{P}, \mathrm{Mg}$, and $\mathrm{Zn}$ in this study decreased as $\mathrm{DIM}$ increased from 3 days to 30 days. $\mathrm{K}$ concentration was higher in Holstein milk than in Jersey milk, while $\mathrm{Zn}$ was higher in the milk of Jersey cows than that of Holstein cows. $\mathrm{Ca}$ and $\mathrm{P}$ in Jersey milk were higher than in Holstein milk. These minerals in milk have an influence on milk coagulation ability [51,52], and are associated with a quick onset of coagulation and high curd firmness rate in the milk processing for cheese [53,54].

The main objective of this study was to compare the major and minor milk compositions be- 
tween primiparous Jersey and Holstein dairy cows fed the same TMR diet at 3 DIM and 30 DIM. In all breed cows, milk protein decreased, and lactose increased as DIM increased. Milk fat, protein, and citrate were higher in Jersey milk than in Holstein milk at 30 DIM. Jersey milk had low the ratio of $\mathrm{C} 18: 1$ to $\mathrm{C} 18: 0$ than that of Holstein milk at $30 \mathrm{DIM}$, and it may be lack of the health benefit factor. However, Jersey milk could be supply more essential AA in proportion to the protein contents. Also, mineral contents related to coagulation ability were higher in Jersey milk than in Holstein milk. Therefore, the current study suggests that Jersey milk be more effective in processing dairy products compared with Holstein milk under the same environmental and nutritional conditions.

\section{REFERENCES}

1. Cheng LJ, Clarke PT, Augustin MA. Seasonal variation in yogurt properties. Aust J Dairy Technol. 2002;57:187-91.

2. Downey L, Doyle PT. Cow nutrition and dairy product manufacture-implications of seasonal pasture-based milk production systems. Aust J Dairy Technol. 2007;62:3-11.

3. Dunshea FR, Walker GP, Williams R, Doyle PT. Mineral and citrate concentrations in milk are affected by seasons, stage of lactation and management practices. Agriculture. 2019;9:25.

4. Yoo J, Song M, Park W, Oh S, Ham JS, Jeong SG, et al. A comparison of quality characteristics in dairy products made from Jersey and Holstein milk. Food Sci Anim Resour. 2019;39:25565.

5. Coleman J, Pierce KM, Berry DP, Brennan A, Horan B. Increasing milk solids production across lactation through genetic selection and intensive pasture-based feed system. J Dairy Sci. 2010;93:4302-17.

6. Gustavsson F, Buitenhuis AJ, Johansson M, Bertelsen HP, Glantz M, Poulsen NA, et al. Effects of breed and casein genetic variants on protein profile in milk from Swedish Red, Danish Holstein, and Danish Jersey cows. J Dairy Sci. 2014;97:3866-77.

7. Palladino RA, Buckley F, Prendiville R, Murphy J, Callan J, Kenny DA. A comparison between Holstein-Friesian and Jersey dairy cows and their F1 hybrid on milk fatty acid composition under grazing conditions.J Dairy Sci. 2010;93:2176-84.

8. Welter KC, Martins CMdMR, de Palma ASV, Martins MM, dos Reis BR, Schmidt BLU, et al. Canola oil in lactating dairy cow diets reduces milk saturated fatty acids and improves its omega-3 and oleic fatty acid content. PLOS ONE. 2016;11:e0151876.

9. Heck JML, Van Valenberg HJF, Dijkstra J, Van Hooijdonk ACM. Seasonal variation in the Dutch bovine raw milk composition.J Dairy Sci. 2009;92:4745-55.

10. Yang L, Yang Q, Yi M, Pang ZH, Xiong BH. Effects of seasonal change and parity on raw milk composition and related indices in Chinese Holstein cows in northern China.J Dairy Sci. 2013;96:6863-9.

11. Stoop WM, Bovenhuis H, Heck JML, Van Arendonk JAM. Effect of lactation stage and energy status on milk fat composition of Holstein-Friesian cows.J Dairy Sci. 2009;92:1469-78.

12. Gurmessa J, Melaku A. Effect of lactation stage, pregnancy, parity and age on yield and major components of raw milk in bred cross Holstein Friesian cows. World J Dairy Food Sci. 2012;7:146-9.

13. Glantz M, Månsson HL, Stålhammar H, Bårström LO, Fröjelin M, Knutsson A, et al. Effects of animal selection on milk composition and processability.J Dairy Sci. 2009;92:4589-603.

14. Cerbulis J, Farrell HM. Composition of the milks of dairy cattle. II. ash, calcium, magnesium, and phosphorus.J Dairy Sci. 1976;59:589-93. 
15. Davies DT, White JCD. 713. The relation between the chemical composition of milk and the stability of the caseinate complex. II. coagulation by ethanol. J Dairy Res. 1958;25:256-66.

16. Donnelly WJ, Horne DS. Relationship between ethanol stability of bovine milk and natural variations in milk composition.J Dairy Res. 1986;53:23-33.

17. Horne DS, Parker TG, Donnelly WJ, Davies DT. Factors affecting the ethanol stability of bovine skim milk. VII. lactational and compositional effects.J Dairy Res. 1986;53:407-17.

18. McGrath BA, Fox PF, McSweeney PL, Kelly AL. Composition and properties of bovine colostrum: a review. Dairy Sci Technol. 2016;96:133-58.

19. Rodríguez-Rodríguez EM, Alaejos MS, Díaz Romero CD. Mineral concentrations in cow's milk from the Canary Island.J Food Compost Anal. 2001;14:419-30.

20. White JCD, Davies DT. 712. The relation between the chemical composition of milk and the stability of the caseinate complex. I. general introduction, description of samples, methods and chemical composition of samples. J Dairy Res. 1958;25:236-55.

21. White JCD, Davies DT. 714. The relation between the chemical composition of milk and the stability of the caseinate complex. III. coagulation by rennet.J Dairy Res. 1958;25:267-80.

22. NRC [National Research Council]. Nutrient requirements of dairy cattle. Washington, DC: National Academies Press; 2001.

23. Bannon CD, Craske JD, Hai NT, Harper NL, O'Rourke KL. Analysis of fatty acid methyl esters with high accuracy and reliability. II. methylation of fats and oils with boron trifluoride-methanol.J Chromatogr A. 1982;247:63-9.

24. Bainbridge ML, Cersosimo LM, Wright ADG, Kraft J. Content and composition of branched-chain fatty acids in bovine milk are affected by lactation stage and breed of dairy cow. PLOS ONE. 2016;11:e0150386.

25. Rastani RR, Andrew SM, Zinn SA, Sniffen CJ. Body composition and estimated tissue energy balance in Jersey and Holstein cows during early lactation. J Dairy Sci. 2001;84:1201-9.

26. White S, Bertrand JA, Wade MR, Washburn SP, Green Jr JR, Jenkins TC. Comparison of fatty acid content of milk from Jersey and Holstein cows consuming pasture or a total mixed ration. J Dairy Sci. 2001;84:2295-301.

27. Rosenthal I. Milk and dairy products: properties and processing. Weinheim: VCH Verlagsgesellschaft; 1991.

28. Kirchgessner M, Kreuzer M, Roth-Maier DA. Milk urea and protein content to diagnose energy and protein malnutrition of dairy cows. Arch Anim Nutr. 1986;36:192-7.

29. Taytak M, Bayram I. Investigation of the interaction between Milk Urea Nitrogen (MUN) and some parameters in determining the level of nutrition in dairy cows. Kocatepe Vet Derg. 2019;12:246-53.

30. Park YK, Koo HC, Kim SH, Hwang SY, Jung WK, Kim JM, et al. The analysis of milk components and pathogenic bacteria isolated from bovine raw milk in Korea J Dairy Sci. 2007;90:5405-14.

31. Wickstrom E, Persson-Waller K, Lindmark-Mansson H, Ostensson K, Sternesjo A. Relationship between somatic cell count, polymorphonuclear leucocyte count and quality parameters in bovine bulk tank milk. J Dairy Res. 2009;76:195-201.

32. Anantakrishnan CP, Khan AQ, Padmanabhan PN. The technology of milk processing. Madras: Shri Lakshmi Publications; 1993.p. 1-25.

33. Nevens WB. Principles of milk production. Jodhpur: Axis books; 2010. p. 256-9.

34. Banerjee GC. A text book of animal husbandry. New Delhi: Oxford; 2009. p. 695-701.

35. Olde Riekerink RGM, Barkema HW, Veenstra W, Berg FE, Stryhn H, Zadoks RN. Somatic cell count during and between milkings. J Dairy Sci. 2007;90:3733-41. 
36. Kennedy BW, Sethar MS, Tong AKW, Moxley JE, Downey BR. Environmental factors influencing test-day somatic cell counts in Holsteins. J Dairy Sci. 1982;65:275-80.

37. Banga CB, Neser FW, Garrick DJ. The economic value of somatic cell count in South African Holstein and Jersey cattle. S Afr J Anim Sci. 2014;44:173-7.

38. Bannerman DD, Springer HR, Paape MJ, Kauf ACW, Goff JP. Evaluation of breed-dependent differences in the innate immune responses of Holstein and Jersey cows to Staphylococcus aureus intramammary infection.J Dairy Res. 2008;75:291-301.

39. Shelley AW, Deeth HC, MacRae IC. A numerical taxonomic study of psychrotrophic bacteria associated with lipolytic spoilage of raw milk.J Appl Bacteriol. 1987;62:197-207.

40. Hanuš O, Vegricht J, Frelich J, Macek A, Bjelka M, Louda F, et al. Analysis of raw cow milk quality according to free fatty acid contents in the Czech Republic. Czech J Anim Sci. 2008;53:17-30.

41. Peterková L. Free fatty acids ratio in milk, factors which affect their concentration and possibilities their determination. In: Problematika prvovýroby mléka, XXVI. Praha: Dum Techniky CVTS; 2002. p. 26-30.

42. Soyeurt H, Dardenne P, Gillon A, Croquet C, Vanderick S, Mayeres P, et al. Variation in fatty acid contents of milk and milk fat within and across breeds.J Dairy Sci. 2006;89:4858-65.

43. Lock AL, Bauman DE. Modifying milk fat composition of dairy cows to enhance fatty acids beneficial to human health. Lipids. 2004;39:1197-206.

44. Van Haelst YNT, Beeckman A, Van Knegsel ATM, Fievez V. Elevated concentrations of oleic acid and long-chain fatty acids in milk fat of multiparous subclinical ketotic cows. J Dairy Sci. 2008;91:4683-6.

45. Medrano J, Johnson A, DePeters E, Islas A. Genetic modification of the composition of milk fat: Identification of polymorphisms within the bovine stearoyl-CoA-desaturase gene. Pflugers Arch. 2000;439(Suppl 1):R24.

46. Ha YL, Storkson J, Pariza MW. Inhibition of benzo(a)pyrene-induced mouse forestomach neoplasia by conjugated dienoic derivatives of linoleic acid. Cancer Res. 1990;50:1097-101.

47. Lp C, Scimeca JA, Thompson HJ. Conjugated linoleic acid. A powerful anticarcinogen from animal fat sources. Cancer. 1994;74 Suppl 3:1050-4.

48. Lynch JM, Barbano DM, Bauman DE, Hartnell GF, Nemeth MA. Effect of a prolonged-release formulation of N-methionyl bovine somatotropin (sometribove) on milk fat. J Dairy Sci. 1992;75:1794-809.

49. Broderick GA, Clayton MK. A statistical evaluation of animal and nutritional factors influencing concentrations of milk urea nitrogen. J Dairy Sci. 1997;80:2964-71.

50. Csapó J, Lóki K, Béri B, Süli Á, Varga-Visi É, Albert C, et al. Colostrum and milk of current and rare cattle breeds: protein content and amino acid composition. Acta Univ Sapientiae Aliment. 2011;4:18-27.

51. Tervala HL, Antila V. Milk with anomalous renneting properties. Jokioinen: State Institute for Dairy Research; 1985.

52. Tsioulpas A, Lewis MJ, Grandison AS. Effect of minerals on casein micelle stability of cows' milk. J Dairy Res. 2007;74:167-73.

53. Bynum DG, Olson NF. Influence of curd firmness at cutting on cheddar cheese yield and recovery of milk constituents.J Dairy Sci. 1982;65:2281-90.

54. Riddell-Lawrence S, Hicks CL. Effect of curd firmness on stirred curd cheese yield. J Dairy Sci. 1989;72:313-21. 